\title{
Meningkatkan Kemampuan Kognitif Anak Usia Dini melalui Pembelajaran Sains
}

\author{
Fardiah', Santosa Murwani'2, Nurbiana Dhieni ${ }^{3}$ \\ Pendidikan Anak Usia Dini, Program Pascasarjana, Universitas Negeri Jakarta \\ DOI: $10.31004 /$ obsesi.v4i1.254
}

\begin{abstract}
Abstrak
Penelitian ini bertujuan untuk meningkatkan kemampuan kognitif melalui pembelajaran sains. Sampel penelitian adalah siswa kelas B PAUD Cikal Harapan 4 Depok Jawa Barat. Teknik pengambilan data dengan menggunakan lembar pengamatan. Teknik analisis data menggunakan deskriptif analitik. Peningkatan kemampuan kognitif pada anak usia dini penting dilakukan karena berdampak pada cara berpikir di kemudian hari. Pembelajaran sains memberi dampak kepada siswa untuk berpikir logis, sistematis. Berdasarkan hasl tersebut maka penelitian ini dilakukan melalui pembelajaran sains. Adapun hasil penelitian selama dua siklus terdapat peningkatan kemampuan kognitif. Disarankan pembelajaran sains dapat digunakan untuk meningkatkan kemampuan lain seperti kemampuan berbahasa.
\end{abstract}

Kata kunci: anak usia dini; kemampuan kognitif; pembelajaran sains

\begin{abstract}
This age needs optimal stimulation so the potential of each child will be able to develop optimally. The aim of this research is to increase the cognitive ability through learning science. This research was concocted using classroom action research and was analytic descriptive. The sample were children of class B Cikal Harapan 4 Preshcool, Depok, West Java. The data was obtained using observation sheets. Increase of cognitive ability in early childhood is important because it will influence the way a child thinks in the future. Science learning makes scholars think logically and systematically. The increase of cognitive ability can be achieved by science learning. The results of two cycles of this research, there was an increase in cognitive ability. Science learning is suggested to be done, as it can increase other abilities, such as linguistic ablity.
\end{abstract}

Keywords: early childhood; cognitive ability; scientific learning

Copyright (c) 2019 Fardiah, Santosa Murwani, Nurbiana Dhieni

$\triangle$ Corresponding author:

Email Address : fardiah1958@gmail.com ( Depok, Jakarta )

Received 3 August 2019, Aceepted 10 October 2019, Published 18 October 2019

\section{PENDAHULUAN}

Pada usia dini merupakan masa emas dalam pertumbuhan dan perkembangan baik secara fisik, emosional, sosial, dan intelektual. Pada masa ini dibutuhkan stimulasi secara optimal sehingga potensi yang dimiliki oleh anak dapat berkembang dan bertumbuh secara optial. Intervensi melalui pembelajaran merupakan salah satu tempat yang tepat untuk mengembangkan potensi anak. Pada pembelajaran dirancang secara sistematis sehingga 
memberi kemudahan cara pengukurannya. Pada saat sekarang ini pembelajaran di Pendidikan Anak Usia Dini (PAUD) kelas B belum menekankan pada peningkatan kemampuan kognitif secara optimal. Salah satu cara mengembang kemampuan kognitif yakni dengan bermain. Kemampuan kognitif yang dapat dikembangkan melalui kegiatan bermain: kemampuan mengenal, mengingat, berpikir konvergen, divergen,memberi penilaian. (Holis, 2013) Pembelajaran dilakukan sebatas memberi pengetahuan pada tingkat rendah belum menuju pada High Order Thinking Skill (HOTS). Higher Order Thinking Skills (HOTS) sebagai keterampilan berpikir siswa dalam memperoleh informasi baru yang disimpan dalam memorinya, selanjutnya menghubungkan dan menyampaikannya untuk tujuan yang diharapkan. (Wahid \& Karimah, 2018) Pembelajaran dengan menekankan pada HOTS di PAUD menjadi keniscayaan agar anak dapat berkembang secara optimal.

Pada konteks pembelajaran tidak dapat dilepas dari kurikulum yang berlaku dan digunakan. Pada kurikulum Tingkat Satuan Pendidikan untuk Taman Kanak-kanak dibagi dalam beberapa bidang seperti bidang pengembangan seni, bidang pengembangan fisik motoric, bidang pengembangan kognitif, bidang pengembangan bahasa, dan bidang pengembangan moral dan agama. Bidang pengembangan ini kemudian diikat pada tema. Tema menjadi penuntun dan petunjuk arah pembelajaran sehingga lebih fokus pada penyampaian materi. Kurikulum PAUD ini digunakan sebagai acuan bagi lembaga PAUD termasuk di dalamnya adalah Taman Kanak-kanak untuk membantu anak didik yang berusia 0-6 tahun mengembangkan seluruh potensinya. Meskipun demikian, pendidik di PAUD memiliki kebebasan untuk memilih cara atau metode atau strategi yang akan diterapkan pada anak didiknya. (Tatminingsih, 2019) Veny Iswantiningtyas \& Widi Wulansari dalam penelitiannya mendapatkan kegiatan pembelajaran diawali dengan sapaan, nyanyian, membahas tema, dan topik. Anak bermain di area-area main yang sudah disetting oleh guru. Kegiatan diakhiri dengan kegiatan recalling, memberikan kesempatan kepada semua anak untuk menceritakan pengalaman main secara bergiliran melalui tanya jawab atau bercerita. (Iswantiningtyas \& Wulansari, 2019). Dalam proses pembelajarannya secara khusus dalam pembelajaran di TK sudah saatnya pengembangan kreativitas anak memperoleh perhatian sehingga dapat mengembangkan berfungsinya kedua belahan otak secara seimbang. (Parwoto, 2017)

Aktifitas pembelajaran pada anak usia dini dapat digunakan untuk mengembangkan kemampuan kognitif. Aktivitas didalam proses belajar mengajar hendaknya ditekankan kepada perkembangan struktur kognitif, melalui pemberian kesempatan kepada anak untuk memperoleh kesempatan secara langsung dalam berbagai aktivitas pembelajaran yang sesuai dengan pembelajaran terpadu dan mengandung makna. (Afrianti, Daulay, \& Asilestari, 2018) Disamping itu anak dapat diberikan pembiasaan untuk mengembangkan sosial emosional mereka sebelum kegiatan pembelajaran. Setiap pagi anak membantu guru membersihkan kelas dan halaman sekolah, selain itu anak juga terbiasa untuk menyiram tanaman yang ada disekolah sebelum kegiatan pembelajaran dimulai. (Nengsi \& Eliza, 2019)

Peningkatan kemampuan kognitif melalui pembelajaran sains pada praktiknya sering dilaksanakan kurang sesuai dengan tujuan dan kurang menyentuh esensi. Hal ini sering dilakukan dengan pemilihan materi, metode, strategi, dan teknik yang kurang sesuai dengan kemampuan anak. Pembelajaran sain sering disampaikan dengan metode ceramah sehingga proses belajar mengajar hanya satu arah terpusat pada guru. Anak kurang dilatih untuk mengembangkan kemampuan kognitif, sehingga pembelajaran kurang menyentuh kebutuhan dan potensi anak dapat berkembang secara optimal.

Pembelajaran dengan menggunakan pendekatan sains untuk meningkatkan kemampuan kognitif pada anak usia dini dirancang sesuai dengan perkembangan berpikirnya. (Woolfolk, 2009) mengutip pernyataan Kilmer dan Hofman bahwa Children engaged in scientific thinking are constructing a frame work of realations within wich factual information can be organized into meaningful and useful concept. Science in an attitude exemplified by curiosity and interest in the world. Science is problem solving. Sciensi is not just learning fact 
and memorizing formula. Pembelajaran dengan menggunakan pendekatan sains pada anak memiliki fungsi penting antara lain melatih anak untuk menghubungkan antara kerangkan kerja otak dengan informasi faktual sehingga memiliki kebermaknaan dalam menguasai konsep.

Beetlesthone mengutip Piaget menyatakan bahwa ada beberapa faktor yang mempengaruhi pertumbuhan intelektual, yakni pengalaman, kedewasaan, transmisi sosial, dan yang paling mendasar, keseimbangan yaitu menemukan keseimbangan dari bendabenda yang sebelumnya belum dipahami. (Florence, 2013) Crain menyatakan bahwa Bandura seperti halnya Piaget melihat anak-anak sebagai agen kognitif aktif menemukan aturan tertentu dan memegang erat konsep yang dibangun di atasnya. Bandura menekankan kepada cara kerja lingkungan eksternal. (Crain, 2005) Peningkatan kemampuan berpikir dapat dilakukan melalui stimulasi dari bermacam- macam arah. Sains merupakan salah satu media atau sarana untuk mengembangkan dan meningkatkan kemampuan berpikir secara logis.

Hergenhahn dan Olso (2008, hlm. 313) menyatakan bahwa intelegensi adalah ciri bawaan yang dinamis sebab tindakan yang cerdas akan berubah saat organisme itu makin matang secara biologis dan mendapat pengalaman. Intelegensi adalah bagian integral dari setiap organisme karena semua organisme yang hidup selalu mencari kondisi yang kondusif untuk kelangsungan hidup mereka.

Omrod (2009, hlm. 211) mengutip Spearman menyatakan bahwa intelegensia sendiri terdari dari (a) kemampuan bernalar yang sifatnya alamiah dan tunggal yang digunakan untuk menyelesaikan berbagai tugas dan (b) sejumlah kemampuan khusus yang digunakan untuk menyelesaikan tugas-tugas spesifik. Pembelajaran sains melalui bermacam-macam percobaan merupakan salah satu media dan sarana untuk mengembangkan cara bernalar sejak usia dini. Pada pembelajaran sains selain kemampuan bernalar anak juga dapat mengembangkan cara berpikir yang spesifik seperti mengembangkan kemampuan atau kecerdasan naturalis.

Woolflok menyatakan bahwa sensory motor (ingatan sensorik) adalah pemrosesan pertama yang menstransformasikan stimuli yang masuk menjadi informasi yang dapat dipahami. (Woolfolk, 2009) Metode ini merupakan sarana atau media merangsang anak agar dapat menggunakan sensorimotor secara baik dan benar.

Beetlesthon (2013, hlm.20-21) menyatakan bahwa bermain memberi kesempatan pada anak-anak untuk berpartisipasi dalam cara mereka sendiri dan mengintepretasikan tugas secara personal serta membiarkan mereka mencoba rute imajiantif tanpa takut akan berbagai macam batasan. Metode bermain memberi ruang kepada anak untuk melakukan eksplorasi sesuai dengan imajinasi dan kemampuannya. Anak melalui bermain dapat menemukan sendiri cara memecahkan suatu masalah yang mungkin tidak terpikirkan sebelumnya. Metode bermain juga memungkinkan anak untuk mengembangkan kreativitas melalui daya imajinasi yang dimilikinya.

\section{METODOLOGI}

Penelitian ini bertujuan untuk berusaha mengumpulkan data apakah kegiatan pembelajaran sains melalui bermain dapat meningkatkan kemampuan kognitif anak usia dini di Kelompok B TK Islam Cikal Harapan Depok. Sedangkan secara khusus penelitian ini bertujuan untuk mengetahui efektivitas pembelajaran sains untuk meningkatkan kemampuan kognitif. Sampel penelitian siswa kelas B

PAUD Islam Cikal Harapan 4 Depok Jawa Barat. Sampel penelitian sebanyak 30 orang anak yang berusia 6 tahun. Sampel terdiri dari anak laki dan anak perempuan. Teknik pengambilan data dengan menggunakan kuesioner. Teknik analisis data dengan menggunakan deskriptif analisis. Metode penelitian dengan menggunakan riset tindakan yang dikembangkan oleh Kemmis dan Taggart seperti terlihat pada gambar berikut ini. 


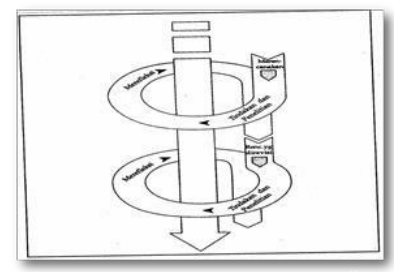

Figure 1. Research steps according to Kermis and Taggart

\section{HASIL DAN PEMBAHASAN}

Tes awal terhadap kemampuan sains dilakukan sebelum dimulai siklus I. Tes kemampuan dilakukan dengan cara wawancara atau tatap muka terhadap anak. Setiap anak menjawab pertanyaan lisan yang ajukan oleh guru. Ada 10 pertanyaan yang harus dijawab. Tes kemampuan awal dibagi menjadi tiga kompetensi yaitu mengenal warna, ukuran, dan bentuk. Berdasarkan tes kemampuan awal kemampuan sains diperoleh data sebagai berikut.

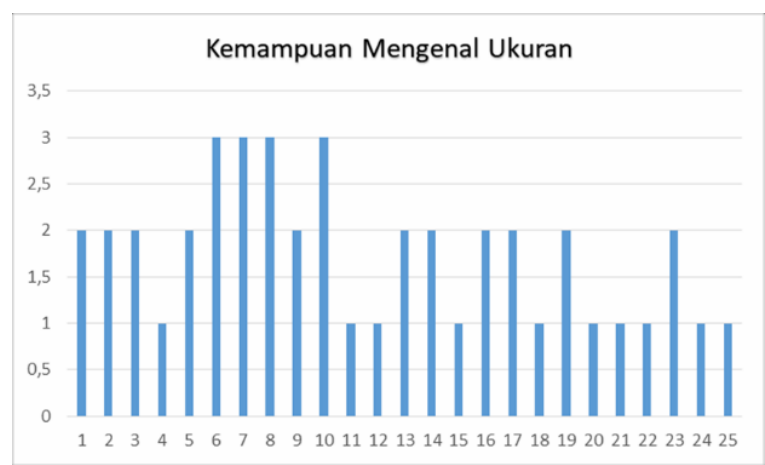

Gambar 1 grafik kemampuan mengenal ukuran

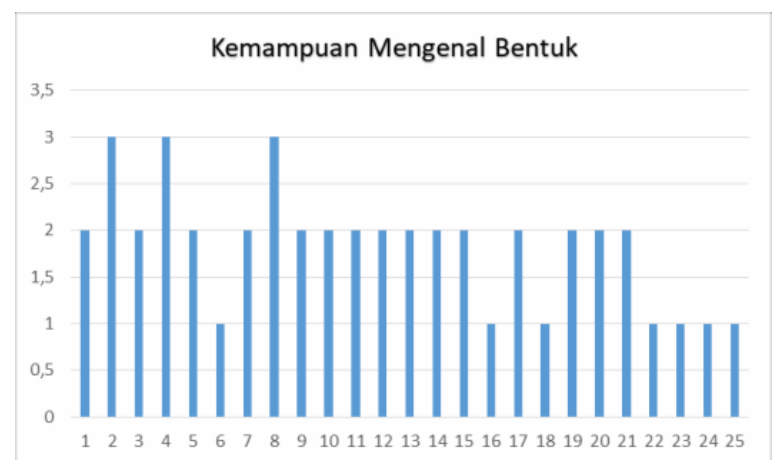

Gambar 2 grafik kemampuan mengenal bentuk

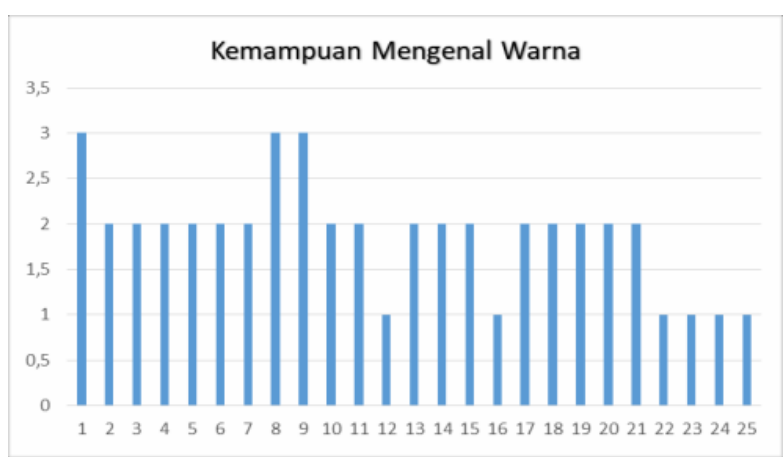

Gambar 3 grafik kemampuan mengenal warna 


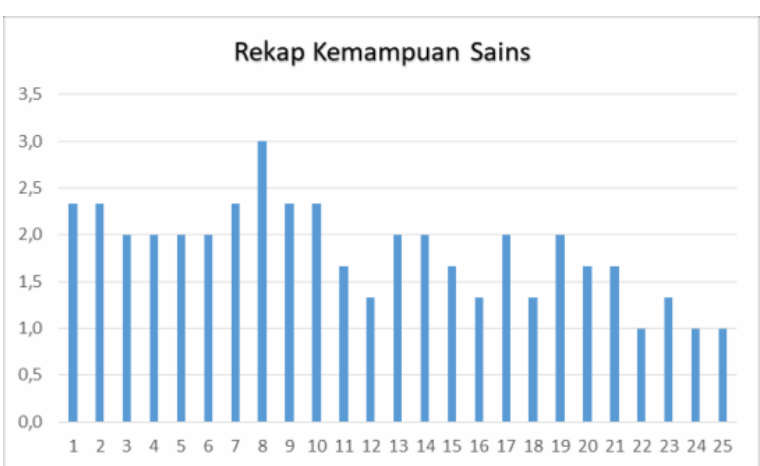

Gambar 4 grafik rekap kemampuan Kogntif

Berdasarkan hasil tes kemampuan awal tersebut dapat dijelaskan kemampuan mengenal ukuran sebesar 1.76 dari rentang maksimum 3.00 atau jika diequvalenkan dengan besaran prosentasi ada sebanyak $58.66 \%$ anak yang sudah mengenal ukuran dan masih ada sekitar $41.34 \%$ memerlukan bimbingan. Pada kemampuan mengenal warna dasar primer sebesar 1.88 dari rentang skor maksimum sebesar 3.00 atau jika diequvalenkan dengan presentasi sebesar 62.66 yang sudah mengenal warna primer sehingga masih ada sekitar $37.34 \%$ memerlukan bimbingan. Pada kemampuan mengenal bentuk rata-rata kelas sebesar 1.84 dari rentang 3.00 atau sebesar 61.33 yang sudah mengenal ukuran sehingga masih ada sekitar $48.67 \%$ memerlukan bimbingan.

Pada pertemuan ke delapan dilakukan tes akhir siklus I. Tes dilakukan dengan teknik tatap muka secara individual yang dilakukan oleh guru. Tiga orang kolaborator menilai hasil belajar yang dilakukan oleh anak. Kolaborator menanyakan kepada siswa tentang bentuk, ukuran, dan warna benda dengan media tanaman. Penilaian dilakukan terutama pada penjelasan yang dilakukan oleh siswa. Pada saat menjelaskan itulah kemampuan siswa dapat terlihat dengan jelas. Siswa dengan kemampuan kognitif baik dapat menjelaskan secara logis sesuai dengan taraf perkembangannya. Siswa dengan kemampuan cukup agak tersendat dalam menjelaskan dan siswa dengan kemampuan kurang cukup lama dalam menjelaskan bentuk, ukuran, maupun warna. Berdasarkan hasil tes akhir siklus satu diperoleh data sebagai berikut.

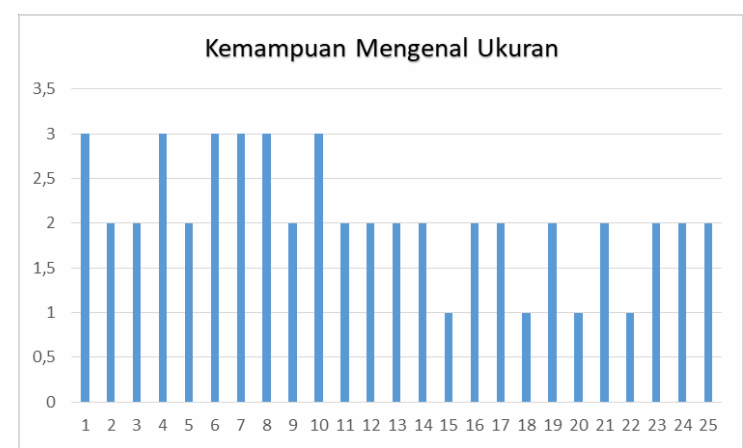

Gambar 5 grafik kemampuan mengenal ukuran

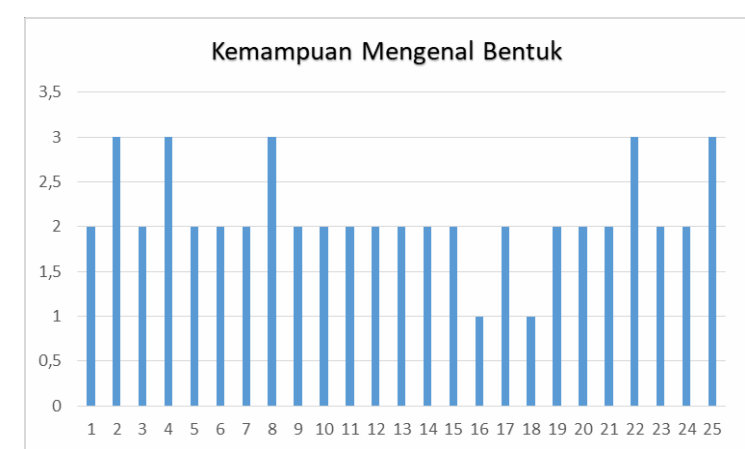

Gambar 6 grafik kemampuan mengenal bentuk 


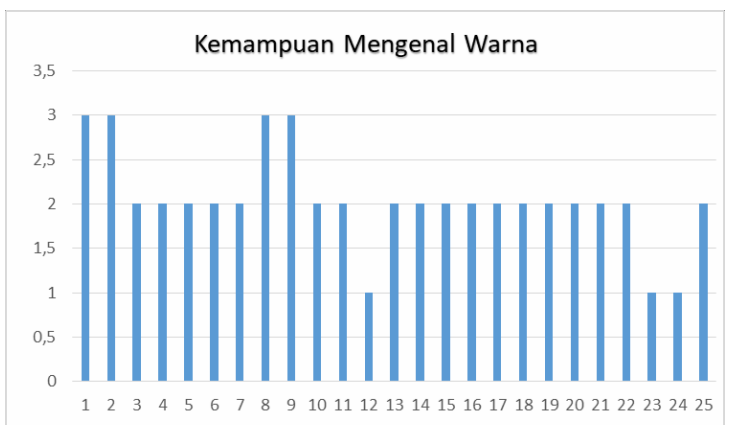

Gambar 7 grafik kemampuan mengenal warna

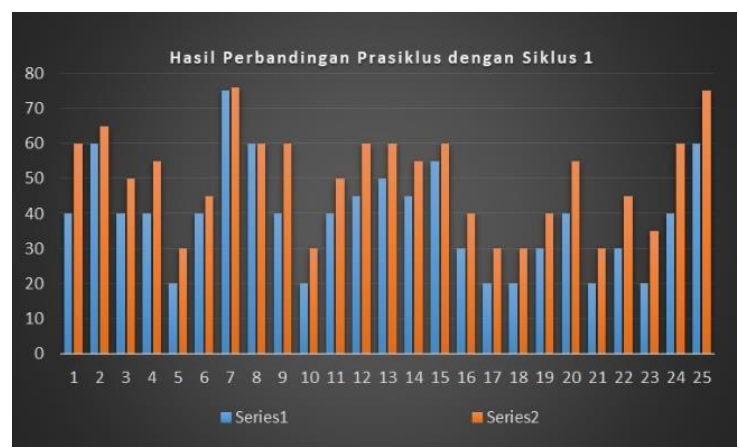

Gambar 8 grafik kemampuan sains tes prasiklus dengan akhir siklus 1

Berdasarkan hasil tes kemampuan mengenal ukuran pada akhir siklus II tersebut dapat dijelaskan pada saat tes kemampuan pada akhir siklus I terjadi sebesar 2.08 pada rentang 3.00 atau sebesar $69.33 \%$ anak sudah mengenal ukuran dan masih ada $20.67 \%$ yang masih memerlukan bimbingan. Pada akhir siklus II terjadi peningkatan yaitu sebesar 3.32 pada rentang 3.00 atau sebesar $77.33 \%$ anak yang sudah mengenal ukuran masih ada sekitar $22.67 \%$ yang masih memerlukan bimbingan.

Pada tes akhir siklus I kemampuan mengenal warna yaitu sebesar 2.04 pada rentang 3.00 atau sebesar $68.00 \%$ dan masih ada sekitar $32.00 \%$ yang masih memerlukan bimbingan. Pada akhir siklus II terjadi peningkatan yaitu sebesar 3.52 pada rentang 3.00 atau sebesar $84.33 \%$ sehingga masih ada sekitar $15.67 \%$ anak yang masih memerlukan bimbingan.

Pada tes akhir kemampuan mengenal bentuk siklus I yaitu sebesar 2.12 pada rentang 3.00 atau sebesar $70.66 \%$ sudah mengenal ukuran dan masih ada $29.34 \%$ yang masih memerlukan bimbingan. Pada tes akhir siklus II terjadi peningkatan yaitu sebesar 2.36 pada rentang 3.00 atau sebesar $78.66 \%$ sehingga masih ada sekitar $21.34 \%$ yang masih memerlukan bimbingan. Berdasarkan rekomendasi dari kolaborator diputuskan tidak diperlukan lagi pada siklus berikutnya karena nilai rata-rata kelas untuk setiap kemampuan sudah di atas $75 \%$.

Berdasarkan hasil tes akhir siklus 2 dapat digambarkan melalui diagram seperti tertera berikut ini.

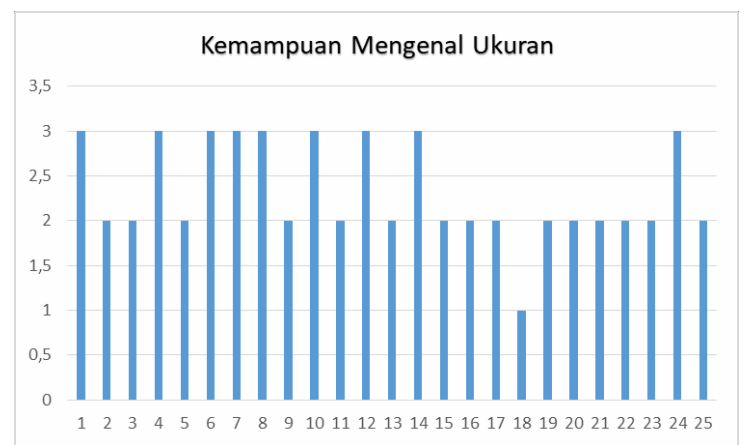

Gambar 9 grafik kemampuan mengenal ukuran 


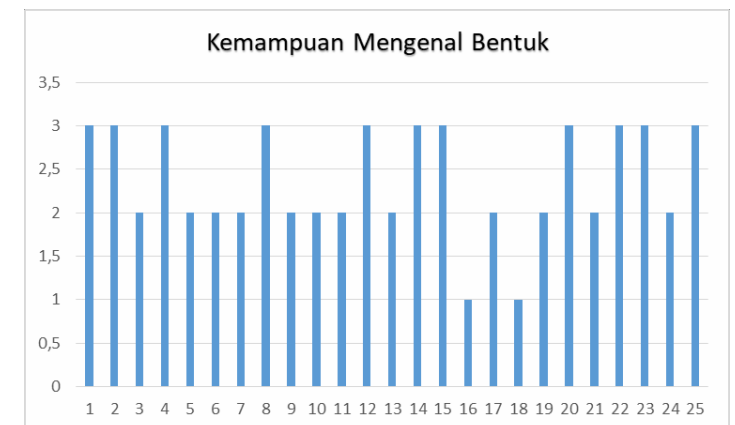

Gambar 10 grafik kemampuan mengenal bentuk

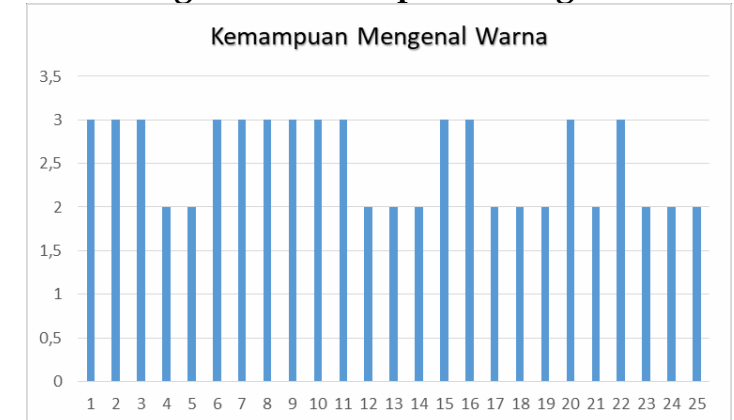

Gambar 11 grafik kemampuan mengenal warna

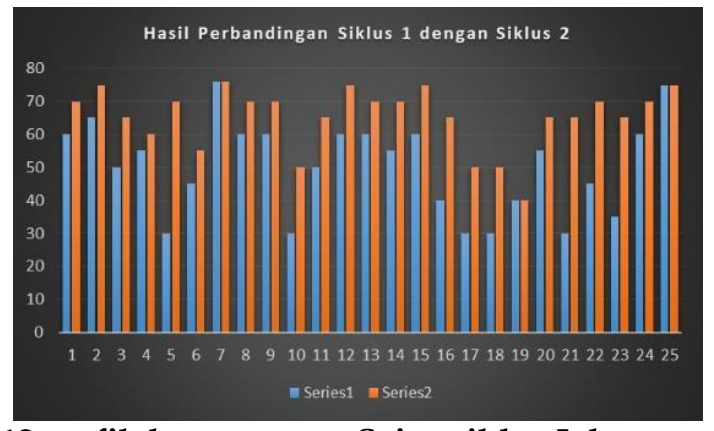

Gambar 12 grafik kemampuan Sains siklus I dengan siklus II

Ada beberapa temuan menarik pada saat pelaksanaan siklus I antara lain. Ada beberapa anak yaitu sampel nomor 17, 18, dan 19 sering tidak dapat fokus terhadap aktivitas di dalam kelas. Ketiga sampel tersebut sering ngobrol sendiri dan sekali kali berlarian di ruang kelas. Duduk senantiasa gelisah karena sering berpindah dari satu tempat ke tempat lainnya. Guru sering membimbing dia untuk dapat bekerja sama dengan teman di dalam kelompok.

Demikian juga ketika dilakukan tes akhir siklus I ketika diminta untuk menyebutkan tentang ukuran, warna, dan bentuk, masih menunggu lama sekali walaupun ibu guru telah memberi beberapa benda-benda yang ada di depan. Pada ukuran berat misalnya, sampel 16, 17, dan 18, diminta untuk menyebutkan angka sesuai dengan jarum yang menunjuk pada angka tersebut masih menunggu lama. Guru memberi bantuan dengan menghitung menggunakan jari tetapi tetap saja sampel tersebut memainkan tangannya dan bendabenda yang ada di atas meja.

Penelusuran guru terhadap ketiga sampel tersebut menunjukkan anak tersebut merupakan anak tunggal dan di rumah hanya dengan Asisten Rumah Tangga. Anak tersebut tidak memiliki teman bermain di lingkungan rumah sehingga ketika ke sekolah merupakan kesempatan untuk bermain sepuasnya. Waktu bermain yang disediakan oleh sekolah dirasa kurang. Pada usia sekitar 7 tahuan belum nampak tanggung jawab karena semua kebutuhan sampel dilakukan Asisten Rumah Tangga. Guru memberi perhatian ekstra terhadap ketiga sampel dengan mengelompokkan tersendiri menjadi satu kelompok 
dengan harapan mereka memiliki tanggung jawab seperti teman sebaya lainnya. Pada siklus I ketiga sampel tersebut memiliki nilai rata rata rendah dibandingkan dengan nilai kelompok lainnya.

Pada siklus II dilakukan selama sembilan kali pertemuan tatap muka. Kemampuan yang ingin dicapai masih sama dengan siklus I yaitu mengenal ukuran, mengenal warna, dan mengenal bentuk. Media pembelajaran menggunakan jenis sayuran seperti kacang panjang, wortel, tomat, lobak, sawi, bayam, pewarna makanan, kertas tissue, karet gelang, gambar sayuran, dan lembar kerja siswa. Jika pada siklu 1 siswa hanya mengenal bentuk, ukuran, dan warna, tetapi pada siklus 2 dikenalkan untuk dapat membedakan dua buah benda. Pada siklus 2 siswa diminta untuk menjelaskan kembali perbedaan dan persamaan antara tumbuhan kangkung dengan bayam. Deskripsi meliputi perbedaan dan persamaan bentuk daun, batang, dan akar. Pada saat siswa mendeskripsikan guru mencatat setiap penjelasan yang dilakukan oleh siswa. Berdasarkan penjelasan tersebut guru menentukan siapa mendapat bintang tiga, dua, dan satu.

\section{SIMPULAN}

Berdasarkan analisis sebelumnya, maka dapat ditarik kesimpulan sebagai berikut; (1) berdasarkan hasil tes pembelajaran sains pada setiap siklus diperoleh data hal ini menunjukkan adanya peningkatan kemampuan kognitif pad anak usia dini kelas B PAUD Cikal Harapan 4 Depok Jawa Barat; (2) metode pembelajaran sains melalui bermain sensormotorik efektif digunakan untuk meningkatkan kemampuan kognitif.

Disaran kepada pihak sekolah untuk menggunakan pembelajaran sains dalam mengembangkan dan meningkatkan kemampuan bidang lain seperti bahasa dan juga seni serta fisik motoric.

\section{DAFTAR REFERENSI}

Afrianti, S., Daulay, M. I., \& Asilestari, P. (2018). Meningkatkan Kemampuan Kognitif Anak dengan Permainan Ludo. Aulad: Journal on Early Childhood, 1(1), 52-59. https:// doi.org/10.31004/aulad.v1i1.6

Crain, W. (2005). Theories of development: Concepts and Applications. New Jersey: Pearson.

Florence, B. (2013). Creative Learning. Bandung: Nusa Media.

Holis, A. (2013). Belajar Melalui Bermain untuk Pengembangan Kreativitas dan Kognitif Anak Usia Dini. Jurnal Pendidikan Islam Garut, 2(1), 23-37.

Iswantiningtyas, V., \& Wulansari, W. (2019). Penanaman Pendidikan Karakter pada Model Pembelajaran BCCT (Beyond Centers and Circle Time). Jurnal Obsesi: Jurnal Pendidikan Anak Usia Dini, 3(1), 110. https:/ / doi.org/10.31004/obsesi.v3i1.106

Nengsi, M. I., \& Eliza, D. (2019). Pelaksanaan Pengembangan Karakter Peduli Lingkungan Bagi Anak dalam Konteks Alam Takambang Jadi Guru. Aulad: Journal on Early Childhood, 2(2), 28-40. https:/ / doi.org/10.31004/aulad.v2i2.32

Parwoto, P. (2017). Pengaruh Penerapan Metode Pembelajaran Collaborative Problem Based Learning (CPBL) terhadap Kreativitas Anak dalam Bermain Komputer. JPUD - Jurnal Pendidikan Usia Dini, 11(1), 97-116. https:// doi.org/10.21009/JPUD.111.07

Tatminingsih, S. (2019). Alternatif Stimulasi Kemampuan Kognitif melalui Penerapan Model Pembelajaran Berbasis Permainan Komprehensif. Jurnal Obsesi: Jurnal Pendidikan Anak Usia Dini, 3(1), 183. https://doi.org/10.31004/obsesi.v3i1.130

Wahid, A. H., \& Karimah, rizka A. (2018). Integrasi Higher Order Thinking Skill (HOTS) dengan Model Creative Problem Solving. MODELING: Jurnal Program Studi PGMI, $5(1), 82-98$.

Woolfolk, A. (2009). Educational Psychology Active Learning Edition. Jakarta: Pustaka Pelajar. 